\title{
The flight display and other behaviors of male lark buntings (Calamospiza melanochorys)
}

\author{
SHANNON V. TAYLOR and VICTOR M. ASHE \\ University of Colorado, Boulder, Colorado 80309
}

\begin{abstract}
The flight display of the male lark bunting (Calamospiza melanochorys) has been hypothesized to function in mate attraction, courtship, and establishment and maintenance of territory. However, empirical support for these suggestions has not yet been provided. The present investigation provides a behavioral analysis of male lark buntings in reproductive condition and documents three phases in the reproductive cycle: preterritorial, territorial, and mated. The flight display was observed in foraging groups of preterritorial males, apparently in response to conspecific flyovers. Solitary territorial males responded to conspecific flyovers (intrusions) with a flight display and pursuit of the intruder. Flight displays were not observed in mated males. The observations suggest that: (1) the communal flight displays of preterritorial males encourage dispersal of the males, and (2) the solitary flight-displays of territorial males subserve establishment and maintenance of territory. Hypotheses are advanced regarding the role of the males' flight display in the reproductive development of females and the absence of these displays during the mating phase.
\end{abstract}

Townsend first reported the striking flight display and rich song of the male lark bunting in 1837 (Baird, Brewer, \& Ridgeway, 1905). Many brief descriptions of the flight display followed (Bailey, 1902; Coues, 1884; Keyser, 1902; Langdon, 1933; Sclater, 1912; Whittle, 1922). Males arrive at spring breeding sites prior to females and remain in flocks. Flight displays are seen at this time as well as during the subsequent period when the males become territorial and begin to court females. Hence, it is not surprising that the above authors hypothesized the flight display to be involved in: (1) establishment and maintenance of territories, (2) mate attraction, and (3) courtship (see also Baumgarten, 1968; Stillwell \& Stillwell, 1955). Although these inferences may prove to be correct, they are currently somewhat tenuous and the data base is incomplete. The present descriptive analysis of the flight display and other behaviors provide a basis for the formulation of testable hypotheses regarding the functional relationships between flight displays, courtship, and territoriality.

\section{METHOD}

\section{Subjects}

The lark bunting (Calamospiza melanochorys, Passeriformes: Emberiyidae) winters in Mexico and breeds in transition and upper sonoran zones from Canada south into Texas and New Mexico (Baumgarten, 1968). Subjects for the present study were found in the Pawnec National Grasslands in Weld County, Colorado. This area can be characterized as upper-sonoran mixed-grass prairie with an annual precipitation of $11 \mathrm{in.} \mathrm{mea-}$ sured at Greeley, Colorado (Gregg, 1963).

This paper is sponsored by Raymond C. Miles, who takes full editorial responsibility for its contents. The authors thank D. Chiszar for his advice during this study.

\section{Procedure}

Identification and recording of behavioral units was facilitated by the use of $7 \mathrm{X}$ binoculars, a $35-\mathrm{mm}$ reflex camera equipped with close-up and telephoto lenses, and a $.10-\mathrm{sec}$ stopwatch. After behavioral units were initially identified $(10 \mathrm{~h}$ of observation), sequences and durations of these units during five observation periods ( $6 \mathrm{~h}$ each) were manually recorded.

\section{RESULTS}

The observations reported here span at least three distinct phases in the reproductive cycle of the male lark bunting. These phases may be labeled in order of their chronological occurrence: preterritorial, territorial, and mated.

\section{Preterritorial}

The onset of this phase is marked by the arrival of male lark buntings at the nesting areas in early May (Graber \& Graber, 1951), in either mixed flocks (Langdon, 1933) or in segregated flocks with males preceding the females by approximately 5 days (Cameron, 1908). Adult males arrive at the nesting grounds in their characteristic black-and-white breeding plumage.

May 6,7, and 8, 1973. The first reconnaissance of the study site revealed an abundance of males, either solitary or in groups of from 2 to 12 individuals. No females were observed. Between communal flight displays, males foraged on the ground in small groups (distance between groups $\geqslant 200 \mathrm{~m}$ ). In addition to the flight display, the following behavioral units were identified and named: (1) hopping $(\mathrm{H})$ was the mode of locomotion lark buntings used on the ground and was seen most often in the context of ground feeding and predation; (2) feeding (F) consisted of a class of feeding postures, i.e., pecking 
at the ground, lunging at locusts, etc.; (3) the upright (UR) posture was a more erect stance than usually seen; (4) wing flicks (WF); (5) tailflicks (TF) were quick but minor extensions of the wing and tail, respectively; (6) feedhop (FH) was used to designate rapid alternation of feeding postures and hopping where it was difficult to record these behaviors separately.

Foraging episodes invariably terminated in a communal flight display involving every member of the foraging group. Each communal flight display was immediately preceded by a flight approach and/or flyover of a conspecific male or by a "spontaneous" (i.e., stimulus undetermined) flight display of a foraging-group member.

The flight display involved a steep ascent ( 5 to $10 \mathrm{~m}$ ), a momentary hover, and an oblique descent, each of which was accompanied by a characteristic song (see Baumgarten, 1968 for song syllables). The angle of ascent is steep and has been estimated to be approximately $50 \mathrm{deg}$ (Scalter, 1912; Whittle, 1922). Field notes indicated that males glided to the ground after $69 \%$ of the displays and to a perch on a fence or shrub after $31 \%$ of the displays. The mean duration of a preterritorial flight display was $13.3 \mathrm{sec}(\mathrm{n}=8, \mathrm{SD}=1.3)$ and the interval between flight displays (i.e., duration of foraging episode) averaged $5.8 \mathrm{~min}(\mathrm{n}=6, \mathrm{SD}=3.2)$.

\section{Territorial Phase}

Observations during this phase indicated that males were for the most part solitary and confined their activity to a circumscribed area.

May 15, 1973. Observations were concentrated in one territorial male whose territory was approximately square and was depicted within the territorial mosaic of the study site (Figure 1). Two boundaries of this territory coincided with prominent features (i.e., a fence

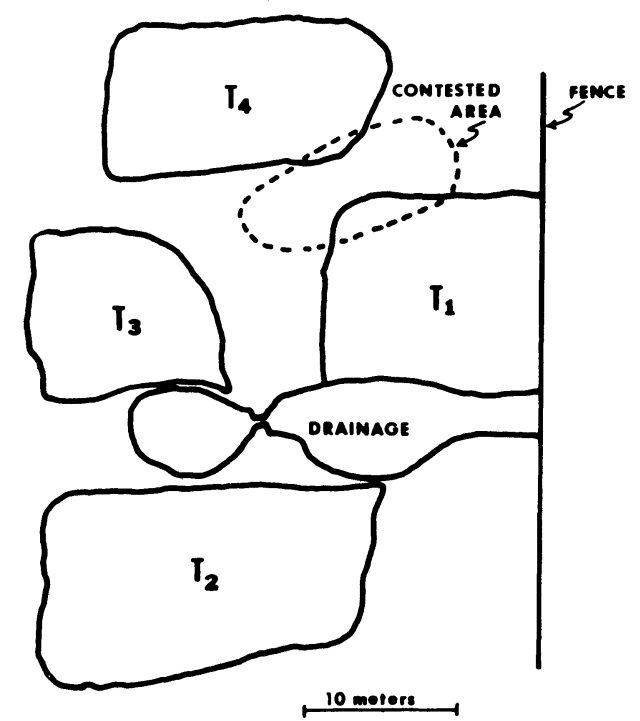

Figure 1. Mosaic of four territories $\left(T_{1}, T_{2}, T_{3}, T_{4}\right)$. Data were collected from the resident of $T_{1}$. and a drainage system). Between flight displays, the behavior of this male consisted only of the behavioral units described for foraging preterritorial males. Foraging was interrupted by flight displays which were either "spontaneous" or apparent responses to conspecific intrusions. If the latter, the resident male invariably pursued the intruder (for a few seconds) after the display. At the completion of the flight display, or at the termination of the pursuit, the resident always alighted in his own territory on a perch (fence or shrub) or on the ground $\left(X^{2}=1.77, \mathrm{df}=1, \mathrm{p}>.05\right)$.

The mean duration of a territorial flight display was $7.1 \mathrm{sec}(\mathrm{n}=6, \mathrm{SD}=1.6)$ and the interval between flight displays averaged only $35.4 \mathrm{sec}(n=40, S D=5.3)$. Both of these measurements are significantly shorter than their counterparts taken from preterritorial males $\left(t_{\text {flight }}\right.$ display $=4.1, d f=12, p<.05 ; t_{\text {between flight }}$ displays $=3.09, \mathrm{df}=44, \mathrm{p}<.05)$. The relatively constant stimulation provided by neighboring males may account for the shorter inter flight display intervals of territorial males.

\section{Mated Phase}

June 5, 1973. Reconnaissance of the study site revealed the conspicuous absence from his territory of the male observed May 15. However, a nest with eggs was discovered in a nearby territory. The male resident in this territory was relatively inconspicuous owing to the fact that he did not call or display at the approach of the authors as did males in previous phases. ${ }^{1}$ The resident male took wing at the authors' intrusion, alighted approximately $200 \mathrm{~m}$ away, and returned after approximately $5 \mathrm{~min}$ to within $10 \mathrm{~m}$ of the nest. An inventory of this male's behavior over the following 10 min included all the behavioral units described for preterritorial foraging males.

Analysis of the data taken from preterritorial, territorial, and mated males during foraging episodes failed to demonstrate any reliable differences between the relative frequencies and/or sequences of the behavioral units, suggesting that male foraging behavior does not change (except for interruption by flight displays) as their reproduction condition cycles.

\section{DISCUSSION}

No females were sighted in the vicinity of displaying males in either the preterritorial or territorial phases; thus, the suspected relationship between the flight display and mate attraction remains unconfirmed. Two copulation episodes were observed, but no flight display was seen on these occasions. The relationship (if any exists) between the flight display and courtship and copulation remains to be established.

The occurrence of flight displays in groups of foraging preterritorial males and in solitary territorial males suggested a relationship between: (1) preterritorial flight displays and dispersion of males, and (2) territorial flight displays and the establishment and maintenance of territory. The fact that no females were observed at the study site during the preterritorial and territorial phases does not preclude the possibility of their in- 
conspicuous presence but does suggest that the females do not interact reproductively with males until after territories are established. It is tempting to speculate further that, owing to the intensity of intermale interaction, the males are oblivious to females in the early phases of the reproductive cycle, but that the females are reproductively stimulated by exposure to the intense display activity of the preterritorial and/or territorial males.

Flight display and intruder pursuit by solitary territorial males clearly suggests a territorial-maintenance function for these behaviors, but the absence of these behaviors during the mated phase was surprising. It could be argued that within a cluster of established territories, the boundaries become stable and. thus, no longer contested, marking the close of the territorial phase. If such proves to be the case, then it is reasonable to speculate that a significant decline in conspecific intrusions leads to a reduction in frequency of flight displays. Also, flight displays during this phase might endanger the eggs by attracting predators. Hence, the territorial function of flight displays during the first two phases may give way to the need for crypticity during the mated phase.

\section{NOTE}

1. Two additional resident males were observed for approximately $1 \mathrm{~h}$, and no flight displays were observed, suggesting that the flight display is not a prevalent behavior of males during the mated phase. In neither case was the resident male's territory intruded upon by conspecific males.

\section{REFERENCES}

BAUMGARTEN, E. H. Lark bunting (Calamospiza melanocorys) Stejneger. In A. C. Bent \& Collaborators, O. L. Austin (Ed.), Life histories of North American cardinals, grosbeaks. buntings, towhees, finches, sparrows, and allies. New York: Dover, 1968. (Originally published as United States National Museum Bulletin No. 237, Smithsonian Institution Press.)

BAILEY, F. M. Handbook of birds of the Western United States. Boston: Houghton, Mifflin, 1902.

BAIRD, S. F., Brewer, T. M., \& RIDGeway, R. North American land birds. (3 Vols.). Boston: Little, Brown, 1905.

Cameron, E. S. The birds of Custer and Dawson Counties. Montana. Auk, 1908, 25, 39-56.

Coues, E. Key to North American birds. Boston: Estes \& Lauriat, 1884.

GRABER; R. \& Graber, J. Notes on the birds of Southwestern Kansas. Transactions of the Kansas Academy of Science. 1951, 54, 145-162.

GREGG, R. E. The ants of Colorado. Boulder, Colo: University of Colorado Press, 1963.

Keyser, L. S. Birds of the Rockies. Chicago: McClurg, 1902.

LANGDon, R. C. The lark bunting. Bird-Lore, 1933, 35, 139-142.

SClater, W. L. A history of the birds of Colorado. London: Witherly, 1912.

Stillwell, J. E. \& Stillwell, N. J. Notes on the song of the lark bunting. Wilson Bulletin, 1955, 67, 138-139.

Whittle, C. L. Miscellaneous bird notes from Montana. Condor, 1922, 24, 73-81.

(Received for publication February 26, 1976.) 